\title{
The effect of feeding sows conjugated linoleic acid (CLA) in late pregnancy on blood thyroid hormone and cholesterol levels in piglets*
}

\author{
M. Pietras, T. Barowicz and M. Pieszka \\ Research Institute of Animal Production, \\ Department of Feed Sciences \\ 32-083 Balice, Poland
}

(Received 15 April 2002; revised version 26 August 2002; accepted 11 October 2002)

\begin{abstract}
The effect of CLA supplementation of feeds for sows in late pregnancy on thyroid hormone, total cholesterol and cholesterol fraction (LDL and HDL) concentrations in the serum of piglets was determined. The experiment was conducted on 8 lactating sows (Large White $\mathrm{x}$ Polish Landrace) divided into two groups. The sows were fed a complete granulated feed with free access to water. From day 90 of pregnancy to delivery, the sows received a $4 \%$ addition of sunflower seed oil or CLA oil (EDENOR UKD 6010, Henkel). Samples of colostrum were taken $24 \mathrm{~h}$ after delivery. Milk samples were taken $3 \mathrm{~h}$ after the morning feeding on days 8 and 21 of lactation. On day 21 , blood from the jugular vein was sampled from two piglets in each litter for determination of thyroid hormone, total cholesterol, HDL and LDL cholesterol. The addition of CLA to the rations of the experimental sows late in pregnancy increased the level of conjugated linoleic acid in colostrum in comparison with the control group $(\mathrm{P}<0.001)$. On days 8 and 21 of lactation the CLA content of milk was lower than in colostrum $(P<0.001)$. Significantly higher levels of thyroxine and triiodothyronine $(P<0.05)$, lower total cholesterol and HDL $(\mathrm{P} \leq 0.05)$ and $\mathrm{LDL}(\mathrm{P} \leq 0.01)$ levels were found in the blood plasma of piglets in the experimental group in comparison with those in the control group.

The obtained results show that conjugated linoleic acid contained in the colostrum of sows increases plasma thyroid hormone levels in the blood of piglets and lowers the levels of total cholesterol and cholesterol fractions.
\end{abstract}

KEY WORDS: CLA, milk, sows, piglets, thyroid hormones, cholesterol

\footnotetext{
* Supported by the State Committee for Scientific Research, Grant No 6 P06E 00620
} 


\section{INTRODUCTION}

Milk is the main food of piglets in the first weeks of life, therefore its composition is of major importance for proper growth and development. It has been demonstrated many times that feeding young animals diets deficient in polyunsaturated fatty acids leads to stunted growth and disease. In recent years particular attention has been focused on the role of conjugated linoleic acid (CLA), which shows a wide spectrum of activity (Pariza, 1997). Studies conducted on many species of animals demonstrated that CLA affects lipid metabolism and body fat content (TsuboyamaKasaoka et al., 2000; Nollette and Miner, 2001; Ramsay et al., 2001; Thiel et al., 2001). The results of numerous experiments have shown that CLA is easily absorbed from the gastrointestinal tract of monogastric animals, and its content in tissues is correlated with the CLA level in consumed feeds (De Deckere et al., 1999; Thiel-Cooper et al., 2001). It was also found that CLA added to rations reduces fat synthesis in cow's (Chouinard et al., 1999) and pig's (Harrell et al., 2000) milk.

Thyroid hormones play an important role in fat metabolism. Field et al. (1986) found that a decline in thyroxine levels in hypothyroid rats caused a rise in plasma cholesterol levels. On the other hand, the secretory activity of the thyroid gland is regulated, among others, by the fatty acid composition of the ration. Fats containing large amounts of mono- and polyunsaturated fatty acids were found to increase blood levels of triiodothyronine (Eder and Kirchgessner, 1997), whereas animal fats lowered the level of this hormone in comparison with vegetable fats (Takeuchi et al., 1995).

The objective of this study was to determine to what extent the addition of CLA to the diets of sows in the late stage of pregnancy affects thyroid hormone and cholesterol levels in the blood of piglets.

\section{MATERIAL AND METHODS}

The experiment was conducted on 8 (Polish Landrace $x$ Large White) lactating sows in their 3-4 lactation. The sows were divided into two groups and fed individually according to Nutrient Requirements of Pigs (1993) with a complete granulated feed with free access to water. On day 90 of pregnancy to delivery, the animals in the experimental group received a $4 \%$ addition of an oil formulation of CLA (EDENOR UKD 6010, Henkel). In the same period, the diet of the control sows was supplemented with $4 \%$ sunflower oil to maintain the same energy value of the diets. Daily rations were adjusted to the production cycle and equaled: up to day 100 of pregnancy, $3 \mathrm{~kg}$; from day 101 to $111,4 \mathrm{~kg}$. Rations were withheld on the day of delivery, while during lactation they were increased to $5-6 \mathrm{~kg}$ depending on the number of piglets in the litter. The average size of the litter at birth was 
11.5 piglets in the control group and 10.25 in the experimental group, while on day 21 , 9.50 and 9.25 , respectively. The piglets were given additional feeds with a prestarter starting from the second week of life. The nutritional value of the feeds and fatty acid composition of the fat in the feeds are given in Table 1. Samples of colostrum were taken within 24 of delivery, whereas that of milk, $3 \mathrm{~h}$ after the morning feeding on days 8 and 21 of lactation. Samples of about $100 \mathrm{ml}$ were obtained manually by milking all of the mammary glands after previous intramuscular administration of $20 \mathrm{IU}$ of synthetic oxytocin. On day 21 of life blood was sampled from the jugular vein from two piglets in each litter for determination of thyroid hormones and cholesterol. The fatty acid composition of oils, colostrum and milk was determined by gas chromatography using a Varian 3400 apparatus and a CP-WAX 58 column after previous extraction of lipids by the method of Folch et al. (1957). Conjugated linoleic acid (CLA) was identified on the basis of a standard obtained from Sigma (O 5507). Thyroxine (T4) and triiodothyronine (T3) were determined in blood plasma by radioimmunological methods using commercially available diagnostic kits, RIA-T4 and RIA-T3; total and HDL cholesterol were determined enzymatically using diagnostic kits from Cormay; the LDL content was calculated mathematically.

The results were subjected to statistical analysis using Statgraphics Plus 4.0 (1999) software.

TABLE 1

Nutritive value (in $1 \mathrm{~kg}$ ) and composition of fatty acids (\% of total fatty acids) of diets

\begin{tabular}{lrr}
\hline \multirow{2}{*}{ Indices } & \multicolumn{2}{c}{ Dows } \\
\cline { 2 - 3 } & 150.00 & Piglets \\
\hline Crude protein, g & 30.00 & 190.00 \\
Ether extract, g & 50.00 & 55.00 \\
Crude fibre, g & 7.50 & 35.00 \\
Ca, g & 7.50 & 8.50 \\
P, g & 9.00 & 4.50 \\
Lysine, g & 5.00 & 13.00 \\
Methioninc + cystine, g & 12.34 & 3.90 \\
Metabolizable encrgy, MJ & & 13.80 \\
& 36.24 & \\
Saturated fatty acids (SF $\Lambda$ ) & 36.67 & 30.74 \\
Mono-unsaturated fatty acids (MUFA) & 27.09 & 33.06 \\
Poly-unsaturated fatty acids (PUFA) & 24.29 & 36.20 \\
PUFA n-6 & & 33.75 \\
\hline
\end{tabular}

\section{RESULTS}

The sunflower oil and the oil CLA preparation used in the experiment contained conjugated linoleic acid in the following amounts, 0.1 and $61.3 \%$, respectively, of 
the total fatty acid content (Table 2). The content of the particular isomers contained in CLA is given in Figure 1.

TABLE 2

Composition of fatty acids in oils, $\%$ of total fatty acids

\begin{tabular}{lcc}
\hline Fatty acids & Sunflower oil & Oil preparation CLA \\
\hline C $12: 0$ & 0.1 & 0.2 \\
C $14: 0$ & 6.5 & 0.1 \\
C $16: 0$ & 0.1 & 4.4 \\
C $16: 1$ & 3.5 & 0.1 \\
C $18: 0$ & 24.6 & 1.8 \\
C $18: 1$ & 63.8 & 29.4 \\
C $18: 2$ n-6 & 0.1 & 2.0 \\
CLA & 0.1 & 61.3 \\
C $18: 3 n-3$ & 0.2 & - \\
C $20: 0$ & - & - \\
C $20: 1$ & 0.4 & 0.3 \\
C $20: 4 n-6$ & - & - \\
C $20: 5 n-3$ & 0.6 & - \\
C $22: 0$ & - & 0.3 \\
C $22: 1$ & - & 0.1 \\
C $22: 6 n-3$ & & - \\
SFA & 10.90 & 6.80 \\
MUFA & 24.70 & 29.80 \\
PUFA & 64.40 & 63.30 \\
PUFA n-6 & 64.20 & 63.30 \\
\hline
\end{tabular}

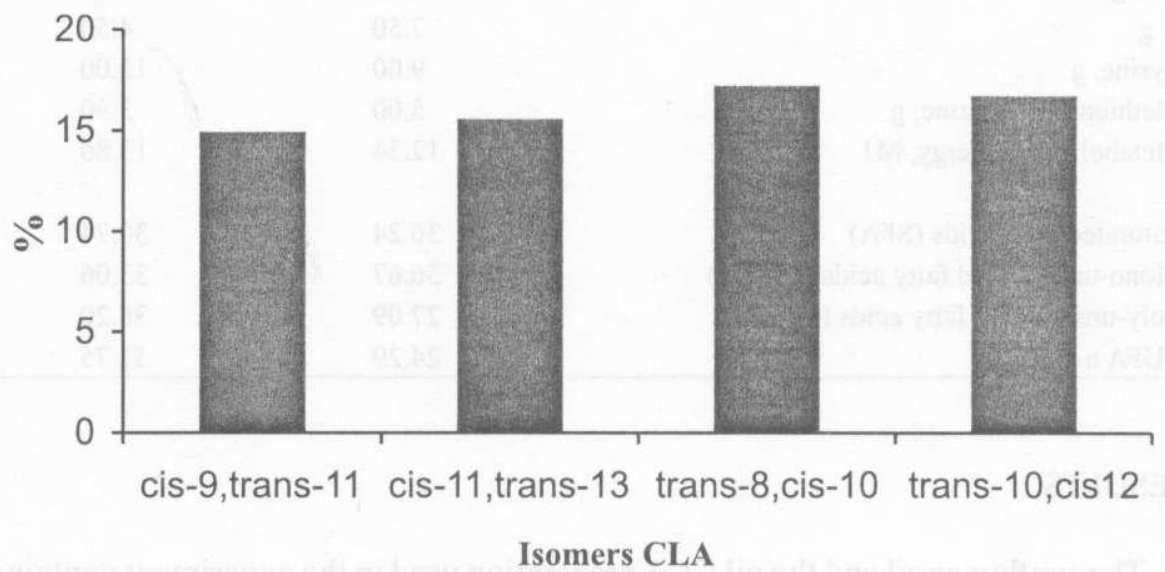

Figura 1. Composition of conjugated linoleic acid izomers in CLA 
On days 8 and 21 of lactation, colostrum and milk contained only small amounts of CLA $(0.5,0.23$ and $0.16 \%$ of total fatty acids $)$ in the group of control sows; the difference in the content of this component in colostrum and milk was not statistically significant. In the group of experimental sows receiving CLA, the CLA content in colostrum was $10.21 \%$ of total fatty acids. On days 8 and 21 of lactation, the level of CLA in milk significantly decreased in comparison with that in colostrum $(\mathrm{P}<0.001)$. The differences between the CLA content in the colostrum of control and experimental sows were significant $(\mathrm{P}<0.001)$, but no significant differences were found between groups in the CLA content of milk (Tabte 3).

TABLE 3

Conjugated linoleic acid content in colostrum ( $24 \mathrm{~h}$ ) and milk of sows, \% of total fatty acids

\begin{tabular}{|c|c|c|c|}
\hline \multirow{2}{*}{ Indices } & \multicolumn{2}{|c|}{ Group } & \multirow{2}{*}{ SEM } \\
\hline & control & experimental & \\
\hline Colostrum & 0.50 & $10.21^{\mathrm{x} \times x}$ & 1.49 \\
\hline \multicolumn{4}{|c|}{ Milk, day of lactation } \\
\hline 8 & 0.23 & 0.70 & 0.17 \\
\hline 21 & 0.16 & 0.22 & 0.03 \\
\hline
\end{tabular}

$\mathrm{xx}-\mathrm{P} \leq 0.001$

Conjugated linoleic acid in colostrum and milk of experimental sows had no effect on the average milk consumption of piglets $(0.96 \mathrm{vs} 0.95 \mathrm{~kg})$ or body weight of piglets on day 21 of life (5.1 vs $5.3 \mathrm{~kg}$ ) in comparison with control animals.

The plasma thyroxine (T4) and triiodothyronine (T3) contents in the experimental group of piglets were significantly higher on day 21 of life than in the control animals (Table 4). The plasma T4/T3 ratio was similar in both groups and the differences were confirmed statistically.

TABLE 4

Thyroid hormones content in blood serum of piglets, $\mathrm{ng} / \mathrm{ml}$

\begin{tabular}{|c|c|c|c|}
\hline \multirow{2}{*}{ Indices } & \multicolumn{2}{|c|}{ Group } & \multirow{2}{*}{ SEM } \\
\hline & control & experimental & \\
\hline$n$ & 8 & 8 & \\
\hline Thyroxine & $46.73^{i}$ & $68.40^{\mathrm{b}}$ & 4.60 \\
\hline Trijodothyronine & 0.79 & $1.05^{\mathrm{h}}$ & 0.06 \\
\hline $\mathrm{T} 4 / \mathrm{T} 3$ & 60 & 66 & 3.12 \\
\hline
\end{tabular}

u.b. $\mathrm{P} \leq 0.05$

The experimental piglets had significantly lower plasma total cholesterol, HDL $(\mathrm{P} \leq 0.05)$ and $\operatorname{LDL}(\mathrm{P} \leq 0.01)$ levels in comparison with control piglets (Table 4). No significant differences were found in the HDL/LDL ratio between the two groups, although a tendency was noted for it to increase in the experimental group. 
TABLE 5

Cholesterol content in blood serum of piglets, mg/dl

\begin{tabular}{lccc}
\hline \multirow{2}{*}{ Indices } & \multicolumn{2}{c}{ Group } & SEM \\
\cline { 2 - 4 } & control & experimental & \\
\hline $\mathrm{n}$ & 8 & 9 & \\
Total cholesterol & 103.07 & $91.98^{\times}$ & 2.28 \\
HDL & 48.65 & $44.45^{\times}$ & 0.98 \\
LDL & 41.98 & $32.18^{\mathrm{xx}}$ & 1.71 \\
HDI.LDL & 1.28 & 1.56 & 0.60 \\
\hline
\end{tabular}

${ }^{x}-P \leq 0.05 ;{ }^{x x}-P \leq 0.01$

\section{DISCUSSION}

The experiments conducted on pigs show that the fatty acid composition of sow milk can be modified through the diet (Taugbol et al..1993; Pietras and Barowicz, 2002). It was also found that providing conjugated linoleic acid (CLA) during lactation increases its concentration in the milk of rats (Chin et al., 1994). In experiments on sows, Bee (2000) compared, among others, the effect of a $2 \%$ addition of sunflower oil enriched with linoleic acid and an oil preparation of CLA in rations fed during pregnancy and lactation on the fatty acid composition of colostrum and milk. He found that the CLA oil preparation significantly increased the concentration of conjugated linoleic acid in the colostrum and milk of sows and affected the long-chain fatty acid composition. The results of our experiment corroborate these findings. The addition of $4 \%$ CLA oil to the feed of sows in the late period of pregnancy significantly increased the amount of CLA in colostrum. On the eighth day of lactation the content of this fatty acid in milk decreased significantly in comparison with colostrum, but still was three-fold higher than in the control group, while on day 21 the CLA level in milk was similar in both groups of sows.

The significantly lower levels of total cholesterol, HDL and LDL in the blood plasma of piglets in the experimental group fed colostrum and milk with an elevated CLA level correspond with the results of other authors and point to a hypocholesterolemic effeet of CLA in animals (Lee et al., 1994; Nikolosi et al., 1997). Szymezyk and Pisulewski (2002) also found a significant reduction in the serum LDL and total cholesterol levels in the liver of rats fed a diet containing $20 \% \mathrm{cgg}$ yolk of eggs enriched with CLA in comparison with a group fed the same amount of standard egg yolks.

The differences in serum cholesterol levels between groups of piglets in our experiment could have been the result of changes in thyroid activity, which plays an important role in cholesterol metabolism. Eder and Stang! (2000) demonstrated 
a significant negative correlation between thyroxine and cholesterol levels in the blood plasma of pigs.

In the present experiment the plasma thyroxine and triodothyronine levels in 21-day-old piglets reared by experimental sows were higher in comparison with piglets from the control group. The significant increase in the level of both thyroid hormones may suggest a stimulatory effect of CLA on the secretory activity of the thyroid gland.

The results obtained by other authors suggest that the fatty acid composition of dietary fat affects the level of thyroid hormones in the blood of animals. Smith et al. (1993) found a lowered level of thyroid hormones in the plasma of rats fed a tallow-containing than in those fed one with sunflower oil. Takeuchi et al. (1995) fed rats a feed containing lard, sunflower oil or linseed oil in amounts of $200 \mathrm{~g} / \mathrm{kg}$ and observed a significant increase in the level of triodothyronine in response to vegetable oils. Eder and Stangl (2000), in turn, found a significant rise in the level of thyroxine, from $42.5 \mathrm{nmol} / \mathrm{l}$ to $56.0 \mathrm{nmol} / \mathrm{l}$, and an increase in the T4/T3 ratio in the plasma of miniature pigs fed a feed containing $15 \%$ sunflower oil oxidized at $110^{\circ} \mathrm{C}$ in comparison with fresh oil.

In summary, it can be said on the basis of these results that conjugated linoleic acid in the colostrum of sows increases the level of thyroid hormones and lowers the level of total cholesterol and HDL and LDL cholesterol in blood plasma. This suggests that the blood cholesterol level of piglets fed conjugated linoleic acid in the colostrum and milk of their dams may and depend on the level of thyroid gland activity.

\section{REFERENCES}

Bee G., 2000. Dietary conjugated linoleic acids alter adipose tissue and milk lipids of pregnant and lactating sows. J. Nutr. 130, 2292-2298

Chin S.F., Storkson J.M., Albright K.J., Cook M.E., Pariza M.W., 1994. Conjugated tinoleic acid is a growth factor for rats as shown by enhanced weight gain and improved feed efficiency. $J$. Nutr. 124, 2344-2349

Chounard P.Y., Comeau L., Barbano D.M., Metzger L.E., Bauman D.E., 1999. Conjugated linoleic acids alter milk fatty acid composition and inhibit milk fat secretion in dairy cows. J. Nutr. $129,1579-1584$

De Deckere E.A.M., van Amelsvoort J.M.M., McNeill G.P., Jones P., 1999. Effect of conjugated linoleic acid (CLA) isomers on lipid levels and peroxisome proliferation in the hamster. Brit. J. Nutr. 82, 309-317

Eder K., Kirchgessner M., 1997. Zum Einfluß versehiedener Fatte auf die Konzentration der Sehilddrüsenhormone im Plasma beim Schwein. J. Anim. Physiol. Anim Nutr. 77, 149-152

Eder K., Stang! G.I., 2000. Plasma thyroxine and cholesterol concentrations of miniature pigs are influenced by thermally oxidized dietary lipids. J. Nutr. 130, 116-121 
Field F.J., Albrigfht E., Matnur S.N., 1986. The effect of hypothyroidism and thyroxine replacement on hepatic and intestinal HMG-CoA reductase and ACAT activities and biliary lipids in the rat. Metabolism 35, 1085-1089

Folch J., Lees M., Stanley G.H.S., 1957. A simple method for the isolation and purification of total lipids from animal tissues. J. Biol. Chem. 226, 497-509

Harrell R.J., Phillips O., Jerome D.L., Boyd R.D., Dwyer D.A., Bauman D.E., 2000. Effects of conjugated linoleic acid on milk composition and baby pig growth in lactating sows. J. Anim. Sci. 77, Suppl.1, 137-138 (Abstr.)

Lee K.N., Kritchevsky D., Pariza M.W., 1994. Conjugated linoleic acid and atherosclerosis in rabbits. Atherosclerosis 108, 19-25

Nicolosi R.J., Rogers E.J., Kritchevsky D., Sciemeca J.A., Huth P.J., 1997. Dietary conjugated linoleic acid reduces plasma lipoproteins and early aotic atherosclerosis in hypercholesterolaemic hamsters. Artery 22, 266-277

Nollette K.R., Miner J.L., 2001. Conjugated linoleic acid and body fat reduction in mice. J. Anim. Sci. 79, Suppl. 2, 109 (Abst.)

Nutrient Requirements of Pigs. Nutritive Value of Feedstuffs (in Polish), 1993. The Kielanowski Institute of Animal Physiology and Nutrition (Editor). Jabłonna (Poland)

Pariza M.W., 1997. Conjugated linoleic acid, a newly recognised nutrient. Chem. Ind., June 16, 464-466

Pietras M., Barowicz T., 2002. Effect of dietary fat on the chemical composition and fatty acid profile of sows colostrum and milk (in Polish). Med. wet. 58, 134-137

Ramsay T.G., Evock-Clover C.M., Steele N.C., Azain M.J., 2001. Dietary conjugated linoleic acid alters fatty acid composition of pig skeletal muscle and fat. J. Anim. Sci. 79, 2152-2161

Smith S.M., Johnson P.E., Lukaski H.C., 1993. In vitro hepatic thyroid hormone deiodination in iron-deficient rats: effect of dietary fat. Life Sci. 53, 603-609

Statgraphics Manugistic Inc., 1999. Startgraphics Plus User Manual, Version 4.0, Manugistic Ins., Rockville, MD

Szymczyk B., Pisulewski P.M., 2002. Feeding conjugated linoleic acid-enriched egg yolks alters serum lipid profile in adult rats. Ann. Anim. Sci. 2, 171-178

Takeuchi H., Matsuo T., Tokuyama K., Susuki M., 1995. Serum triiodothyronine concentration and $\mathrm{Na}^{+}, \mathrm{K}^{+}$- ATPase activity in liver and skeletal muscle are influenced by dietary fat type in rats. J. Nutr. 125, 2364-2369

Taugbol O., Framstad T., Saarem K., 1993. Supplements of cod liver oil to lactating sows. Influence on milk fatty acid composition and growth performance of piglets. J. Vet. Med. 40, 437-443

Thiel R.L., Sparks J.C., Wiegand B.R., Parrish F.C. Jr., Ewan R.C., 1998. Conjugated linoleic acid improves performance and body composition in swine. J. Anim. Sci. 76, Suppl. 2, 57 (Abstr.)

Thiel-Cooper R.L., Parrish F.C., Sparks J.C., Wiegand B.R., Ewan R.C., 2001. Conjugated linoleic acid changes swine performance and carcass composition. J. Anim. Sci. 79, 1821-1828

Tsuboyama-Kasaoka N., Takahashi M., Tanemura K., Kim H.J., Tange T., Okuyama H., Kasai M., Ikemoto S., Ezaki O., 2000. Conjugated linoleic acid supplementation reduces adipose tissue by apoptosis and developes lipodystrophy in mice. Diabetes $49,1534-1542$ 


\section{STRESZCZENIE}

Wpływ podawania lochom w końcowym okresie ciąży sprzężonego kwasu linolowego (CLA) na zawartość hormonów tarczycy i cholesterolu we krwi prosiąt

Określano wpływ CLA dodanego do paszy loch w ostatnim okresie ciąży na zawartość hormonów tarczycy, cholesterolu całkowitego oraz cholesterolu we frakcjach lipoproteinowych LDL i HDL w osoczu krwi prosiąt. Doświadczenie przeprowadzono na 8 lochach (wbp x pbz) podzielonych na 2 grupy. Lochy żywiono pełnodawkową mieszanką granulowaną przy stałym dostępie do wody. Od 90 dnia ciąży do wyproszenia lochy otrzymywały $4 \%$ dodatek oleju słonecznikowego lub oleju CLA (EDENOR UKD 6010, Henkel). Próbki siary pobierano w 24 godz. od wydalenia łożyska, a próbki mleka w 3 godz. po rannym odpasie w 8 i 21 dniu laktacji. W 21 dniu życia prosiąt pobrano krew z żyły jarzmowej w celu oznaczenia zawartości hormonów tarczycy i wskaźników lipidowych. Wprowadzenie preparatu CLA do dawek pokarmowych dla loch doświadczalnych w ostatnim okresie ciąży zwiększyło poziom sprzężonego kwasu linolowego w siarze w porównaniu z grupą kontrolną $(\mathrm{P}<0,001)$. W 8 i 21 dniu laktacji zawartość CLA w mleku loch grupy doświadczalnej obniżyła się w porównaniu z siarą $(\mathrm{P}<0,001)$. Zawartość tyroksyny i trójjodotyroniny w osoczu krwi prosiąt z grupy doświadczalnej w 21 dniu życia była istotnie wyższa $(\mathrm{P}<0,05)$, natomiast zawartość cholesterolu całkowitego, HDL $(\mathrm{P} \leq 0,05)$ i LDL $(\mathrm{P} \leq 0,01)$ niższa w porównaniu z prosiętami grupy kontrolnej.

Uzyskane wyniki wskazują, że sprzężony kwas linolowy zawarty w siarze loch zwiększa zawartość hormonów tarczycy w osoczu krwi prosiąt oraz obniża poziom cholesterolu całkowitego i cholesterolu we frakcjach lipoproteinowych. 